Deden • U. Umiyati

\title{
Pengaruh inokulasi Trichoderma $s p$ dan varietas bawang merah terhadap penyakit moler dan hasil tanaman bawang merah (Allium ascalonicum $\mathrm{L}$ )
}

\section{The effect of Trichoderma sp inoculation and shallot "Bawang merah" variety on moler diseases and yield of shallot}

Diterima : 17 Agustus 2017/Disetujui : 25 Agustus 2017 / Dipublikasikan : 31 Agustus 2017

CDepartment of Crop Science, Padjadjaran University

\begin{abstract}
One of important diseases in onion crops is moler. Currently, the various studies have reported avoiding using fungicides in controlling of Molar diseases. One of the ways to control this disease is by biological control such the Trichoderma sp. The purposes of this research were to know the effect and interaction between Trichoderma sp and Shallot variety on moler disease and yield of Shallot. Research carried out in villages Playangan, Gebang, Cirebon - West Java, from June to August 2016. The Randomized Complete Block Design with factorial pattern was used in this study and three times replication. In which, the treatment of Trichoderma consisted four levels and three levels of Shallot variety. The result showed the interaction between Trichoderma and Shallot variety on number of leaves and weights of the dried tubers. Besides, the independent effects of Trichoderma on height of plant, number of leaves, plant biomass and weights of the dried tubers per clump. The independent effects of Shallot were found on average in height of plant, number of leaves, the number of puppies per clump, and weights of the dried tubers per clump. Furthermore, the strong correlation between components real growth tall plant age four week after treatment and number of leaves the age of five and six week after treatment weight against the results of the dried tubers was found in this study
\end{abstract}

Keywords: Onion $\cdot$ Trichoderma $\cdot$ Moler disease

\footnotetext{
Dikomunikasikan oleh Fiky Yulianto Wicaksono

Deden $^{1} \cdot$ U. Umiyati $^{2}$

${ }^{1}$ Dosen Fakultas Pertanian Unswagati Cirebon

2 Dosen Fakultas Pertanian Unpad

Korespondensi:
}

Sari Salah satu penyakit yang sering dijumpai pada tanaman bawang merah adalah penyakit moler. Saat ini pengendalian penyakit Moler masih bertumpu pada penggunaan kimia (Fungisida). Salah satu agen hayati yang sudah terbukti berperan ampuh sebagai pengendali hayati yaitu Trichoderma sp. Tujuan dari penelitian ini adalah (1) Untuk mengetahui pengaruh dan interaksi antara Trichoderma $S p$ dan varietas bawang merah terhadap pengendalian penyakit moler dan hasil tanaman bawang merah (Allium ascalonicum), (2) Untuk mengetahui jenis dan dosis Trichoderma $S p$ dan varietas yang paling baik mengendalikan penyakit moler dan dapat meningkatkan tanaman bawang merah (Allium ascalonicum), (3) Untuk mengetahui korelasi terhadap komponen pertumbuhan dan hasil tanaman bawang merah (Allium ascalonicum.). Penelitian dilaksanakan di Desa Playangan, Gebang, Cirebon - Jawa Barat, dari bulan Juni-Agustus 2016. Metode penelitian yang digunakan Rancangan Acak Kelompok (RAK) pola faktorial. Perlakuan terdiri dari dua faktor yang diulang tiga kali. Faktor pertama adalah Trichoderma (T) terdiri dari 4 perlakuan., sedangkan faktor yang kedua adalah varietas bawang merah $(\mathrm{V})$ yang terdiri dari 3 perlakuan. Hasil penelitian menunjukan terdapat pengaruh interaksi yang nyata antara Trichoderma dan varietas bawang merah terhadap parameter rata-rata jumlah daun 6 MST, dan bobot umbi kering per petak. Terdapat efek mandiri dari perlakuan Trichoderma terhadap rata-rata tinggi tanaman 4 dan 5 MST, jumlah daun 5 MST, biomassa tanaman 5 dan 6 MST, dan bobot umbi kering per rumpun, serta efek mandiri varietas bawang merah pada rata-rata tinggi tanaman 4 , 5 ,6 MST, jumlah daun 4 dan 5 MST, jumlah anakan per rumpun, dan bobot umbi kering per 
rumpun. Terdapat korelasi yang nyata antara komponen pertumbuhan tinggi tanaman umur 4 MST dan jumlah daun umur 5 dan 6 MST terhadap hasil bobot umbi kering per petak.

Kata kunci : Bawang merah • Trichoderma sp • Penyakit moler.

\section{Pendahuluan}

Bawang merah (Allium ascalonicum L.) merupakan salah satu komoditas sayuran unggulan yang sejak lama telah diusahakan oleh petani secara intensif, khusunya Petani di Wilayah Cirebon bagian timur. Komoditas ini merupakan bagian penting dari bumbu masakan, baik untuk masakan rumah tangga, restoran maupun bahan industri makanan, di samping itu bawang merah juga bisa di manfaatkan sebagai obat herbal. Bawang merah dapat digunakan untuk obat penyakit diabetes melitus, menurunkan kolesterol dan kadar gula, menghambat penumpukan trombosit, meningkatkan aktifitas fibrinolitik sehingga dapat memperlancar aliran darah (Wibowo, 2007).

Fenomena meningkatnya permintaan pasar, membuat bawang merah menjadi komoditas yang ketersediaanya kian diperhitungkan oleh Pemerintah dalam rangka menjaga stabilitas ekonomi Indonesia. Berdasarkan Badan Pusat Statistik (2013), produksi umbi bawang merah indonesia sebanyak 1,011 juta ton. Jumlah rumah tangga usaha bawang merah adalah 226.224 rumah tangga. Provinsi dengan jumlah rumah tangga usaha bawang merah terbesar adalah Jawa Tengah dan Jawa Barat (Cirebon). Secara nasional, luas tanam bawang merah adalah sebesar 587.667,074 $\mathrm{m}^{2}$, sedangkan ratarata luas tanam yang dikelola per rumah tangga adalah 2597 m²$^{2}$. Cirebon merupakan Kabupaten penghasil bawang merah tertinggi di Jawa Barat. Produksi bawang merah di Cirebon pada tahun 2013 mencapai 36.449 ton.

Kebutuhan bawang merah nasional harus dapat dihitung dan disiapkan secara cermat, sehingga kedepan tidak ada ketimpangan antara kebutuhan dan produksi. Permintaan dan kebutuhan bawang merah setiap tahun selalu mengalami peningkatan, namun belum dapat diimbangi dengan peningkatan produksinya. Serangan patogen tanaman merupakan salah satu kendala yang sering dihadapi dalam budidaya bawang merah. Salah satu penyakit yang sering dijumpai pada tanaman bawang merah adalah penyakit moler, yang pada akhirakhir ini seakan kompak menyerang tanaman petani di Kabupaten Cirebon. Penyakit moler merupakan penyakit yang menurut para petani saat ini menjadi pengganggu paling mematikan pada budidaya bawang merah, dan sangat sulit dikendalikan. Penyakit moler diduga disebabkan oleh Fusarium oxysporum (Departemen Pertanian, 2003).

Saat ini pengendalian penyakit moler masih bertumpu pada penggunaan fungisida. Penggunaan bahan kimia yang terus menerus mengakibatkan degradasi lingkungan, dan menyebabkan ketahanan penyakit terhadap fungisida tertentu yang sering dipakai semakin kuat. Perlu dipertimbangkan pilihan lain yang lebih efektif dan ramah lingkungan. Salah satu agen hayati yang sudah terbukti berperan ampuh sebagai pengendali hayati yaitu Trichoderma $s p$. Trichoderma sp lebih efektif dan ramah lingkungan untuk mengurangi persen-tase dan intensitas penyakit moler dan layu pada tanaman bawang merah. Trichoderma sp merupakan sejenis cendawan/fungi yang termasuk kelas ascomycetes. Trichoderma sp memiliki aktivitas antifungal. Trichoderma banyak ditemukan di tanah hutan maupun tanah pertanian atau pada substrat berkayu (Samuels, et al., 2010).

Salah satu perusak budidaya bawang merah adalah serangan penyakit moler. Menurut Wiyatiningsih (2007), penyakit moler merupakan penyakit pada bawang merah dengan gejala penyakit yaitu batang semu dan daun tumbuh lebih panjang dan meliuk. Besarnya kerugian yang ditimbulkan oleh penyakit moler belum diketahui secara pasti dikarenakan terbatasnya informasi mengenai penyakit tersebut. Oleh karena itu, diperlukan penelitian yang mampu memberikan informasi mengenai penyakit moler pada bawang merah. Salah satu pilihan pengendalian yang tepat dan perlu diupayakan adalah pengendalian dengan menggunakan agensia hayati, seperti Tricho-derma harzianum.

T. harzianum mampu menekan F. oxysporum f.sp. gladioli penyebab layu pada tanaman gladiol (Rokhlani, 2005) dan F. oxysporum f.sp. zingiberi (Soesanto et al., 2005; Prabowo et al., 2006). Selain itu, T. harzianum dan T. koningii juga mampu dalam mengendalikan jamur Rigidoporus microporus pada tanaman karet (Basuki, 1986 dalam Sudantha, 2003).

Upaya peningkatan produksi, bibit merupakan salah satu faktor utama yang menentukan 
keberhasilan usaha tani. Menurut pengalaman para Petani di Cirebon, menceritakan bahwa jenis varietas juga mepengaruhi tingkat kerentanan serangan penyakit Moler bawang merah. Para petani di Cirebon, biasanya sering menggunakan varietas Bima, Sumenep, Philipin, dan Ilokos. Pendugaan petani, varietas Bima lebih tahan moler dari pada varietas lainya. Hal ini perlu dibuktikan dengan penelitian lebih lanjut untuk mengungkap anggapan tersebut. Selain itu juga, cerahnya prospek usahatani bawang merah di Cirebon, maka perlu adanya terobosan teknologi budidaya agar produktivitas bawang merah lebih baik lagi. Keadaan ini berpengaruh baik terhadap perolehan pendapatan. Apalagi didukung dengan cepatnya perputaran modal usaha bawang merah.

Usahatani bawang merah di Cirebon masih terganggu adanya penyakit moler,. Inokulasi Trichoderma $\mathrm{Sp}$ dan varietas bawang merah berpengaruh terhadap ketahanan penyakit moler dan hasil bawang merah (Allium ascalonicum)".

\section{Metode Penelitian}

Penelitian dilaksanakan di Desa Playangan, Kecamatan Gebang, Kabupaten Cirebon - Jawa Barat. Lokasi penelitian merupakan wilayah bianaan UPTD BP4K (Balai Penyuluhan Pertanian, Peternakan, dan Perkebunan) Kecamatan Gebang Kabupaten Cirebon. Terletak pada ketinggian 3 meter di atas permukaan laut (m $\mathrm{dpl})$, jenis tanah grumosol.

Bahan yang digunakan dalam penelitian ini adalah 2 jenis Trichoderma yaitu Trichoderma harzianum dan Trichoderma koningii dan tiga varietas bibit bawang merah, yaitu Varietas Bima, Ilokos dan Sumenep. Pemupukan menggunakan pupuk Urea $(\mathrm{N})$, pupuk SP36 (P), dan pupuk $\mathrm{KCl}(\mathrm{K})$. Sedangkan untuk mengendalikan organisme pengganggu tanaman menggunakan inseksitisa dan fungisida sesuai kebutuhan. Alat-alat yang digunakan dalam percobaan ini adalah cangkul, kored, sabit, tugal, meteran, penggaris, timbangan, papan nama, bambu/ajir, hand sprayer, alat tulis, dan alat perlengkapan laboratorium.

Metode percobaan yang digunakan yaitu menggunakan metode Rancangan Acak Kelompok (RAK) pola faktorial, ukuran petak $1 \times 3 \mathrm{~m}$, jarak antar petak $30 \mathrm{~cm}$, jarak antar ulangan 100 $\mathrm{cm}$, sedangkan jarak tanam $20 \times 15 \mathrm{~cm}$. Perlakuan terdiri dari dua faktor yaitu faktor yang pertama Trichoderma, sedangkan faktor yang kedua adalah varietas bawang merah, dengan rancangan sebagai berikut

Faktor pertama, Trichoderma yang terdiri atas 4 varietas $(\mathrm{T})$ yaitu:

1. $\mathbf{t}_{1}=$ Tanpa Aplikasi Trichoderma

2. $t_{2}=$ Aplikasi Trichoderma harzianum 5 $\mathrm{ml} /$ liter

3. $\mathrm{t}_{3}=$ Aplikasi Trichoderma koningii $5 \mathrm{ml} /$ liter

4. $t_{4}=$ Aplikasi Trichoderma harzianum 2,5 $\mathrm{ml} /$ liter dan Trichoderma koningii 2,5 ml/liter

Faktor kedua, varietas bawang merah yang terdiri dari 3 perlakuan $(\mathrm{V})$ yaitu :

1. $\mathrm{v}_{1}=$ Varietas Bima

2. $\mathrm{v}_{2}=$ Varietas Ilokos

3. $\mathrm{v}_{3}=$ Varietas Sumenep

Masing-masing perlakuan diulang tiga kali sehingga jumlah petak dalam penelitian sebanyak $4 \times 3 \times 3=36$ petak.

Penelitian lapangan, meliputi kegiatan budidaya (pengolahan tanah, penyiapan bibit, penanaman, pemeliharaan, dan pemanenan). Sedangkan penelitian laboratorium dilakukan untuk anaslis tanah. Pengamatan penunjang dilakukan terhadap hasil analisis tanah sebelum percobaan, curah hujan, serangan hama, penyakit dan gulma. Pengamatan utama dilakukan terhadap berbagai komponen pertumbuhan dan produksi serta penyakit moler pada tanaman.

Intensitas penyakit moler diamati dengan cara dihitung persentase tanaman bawang merah yang terkena penyakit moler dengan menggunakan rumus (Rosmahani et al., 2003) :

$$
\mathrm{IP}=\frac{\mathrm{A}}{\mathrm{N}} \times 100 \%
$$

Keterangan :

IP $=$ Persentase intensitas penyakit.

$\mathrm{A}=$ Jumlah tanaman yang sakit

$\mathrm{N}=$ Jumlah tanaman sampel

Uji hipotesis bagi efek perlakuan dilakukan dengan menggunakan uji $\mathrm{F}$ dan dilanjutkan dengan uji jarak berganda Duncan taraf $5 \%$, rumusnya dalam Warsa dan Akhyar (1982). Untuk mengetahui korelasi antara komponen pertumbuhan dan hasil bawang merah menggunakan koefisien korelasi yang dikemukakan oleh Wijaya (2000). 


\section{Hasil dan Pembahasan}

Pengamatan yang diamati meliputi penyakit moler, tinggi tanaman, jumlah daun, biomassa per rumpun, jumlah anakan, diameter umbi, bobot umbi kering per rumpun dan per petak yang diuji secara statistik.

Serangan Penakit Moler. Berdasarkan data pada Tabel 1 menunjukkan tidak terdapat interaksi antara perlakuan Trichoderma $s p$ dan varietas bawang merah terhadap pengendalian penyakit moler, ada perbedaan yang nyata dari petak tanaman bawang merah yang diberi Trichoderma dengan petak tanaman bawang merah yang tidak diberi Trichoderma, petak yang tidak diberi Trichoderma ( $\left.\mathrm{t}_{1}\right)$ secara signifikan menunjukan adanya serangan penyakit moler yang tinggi mencapai $1,84 \%$ pada umur 4 MST dan 1,90 pada umur pengamatan 5 MST, sedangkan pada hasil pengamatan 6 MST tidak berbeda nyata dengan perlakuan lainya. Hal ini diduga karena keberadaan Trichoderma yang diaplikasikan saat pengolahan tanah pada petak percobaan sudah semakin berkurang pada umur 6 MST. Dugaan selanjutnya yaitu dalam rangka menstabilkan jumlah Trichoderma pada petak percobaan perlu penyemprotan susulan pada umur tanaman menjelang 6 MST, sehingga akan dapat menekan serangan moler tanaman bawang merah sampai panen, Adapun perlakuan penelitian yang berpengaruh paling baik terhadap pengendalian penyakit moler dihasilkan dari perlakuan $t_{4}$ (T. harzianum 2,5 $\mathrm{ml} /$ liter dan $T$. koningii $2,5 \mathrm{ml} /$ liter) dengan menunjukan tingkat serangan paling kecil yaitu hanya $0,78 \%$, Adapun dari hasil pengamatan, perlakuan jenis varietas bawang merah secara umum tidak begitu berpengaruh terhadap timbulnya penyakit moler, hanya varietas bima pada hasil pengamatan 4 MST terlihat adanya perbedaan serangan moler bila dibandingkan dengan varietas lainya yang digunkan dalam penelitian.

Tinggi Tanaman (cm). Hasil analisis statistik menunjukan tidak terjadi interaksi antara perlakuan Trichoderma dan varietas bawang merah terhadap hasil rata-rata tinggi tanaman bawang merah pada hasil pengamatan umur 4, 5, dan 6 MST, Namun secara mandiri perlakuan Trichoderma dan varietas bawang merah berpengaruh pada hasil tinggi tanaman, Hasil analisis statistik tersebut seperti tercantum pada Tabel 2.
Tabel 1. Pengaruh Trichoderma dan Varietas Bawang Merah terhadap Rata-rata Serangan Penyakit Moler Tanaman (\%).

\begin{tabular}{lccc}
\hline \hline Perlakuan & \multicolumn{3}{c}{ Serangan Moler (\%) } \\
\cline { 2 - 4 } & 4 MST & $5 \mathrm{MST}$ & $6 \mathrm{MST}$ \\
\hline Trichoderma $(\mathrm{T})$ & & \\
$\mathrm{t}_{1}$ & $1,84 \mathrm{~b}$ & $1,90 \mathrm{~b}$ & $1,19 \mathrm{a}$ \\
$\mathrm{t}_{2}$ & $0,96 \mathrm{a}$ & $1,13 \mathrm{a}$ & $1,29 \mathrm{a}$ \\
$\mathrm{t}_{3}$ & $0,83 \mathrm{a}$ & $1,12 \mathrm{a}$ & $1,28 \mathrm{a}$ \\
$\mathrm{t}_{4}$ & $0,78 \mathrm{a}$ & $1,07 \mathrm{a}$ & $1,54 \mathrm{a}$ \\
\hline \multicolumn{2}{l}{ Varietas bawang Merah $(\mathrm{V})$} \\
$\mathrm{v}_{1}$ & & \\
$\mathrm{v}_{2}$ & $1,38 \mathrm{a}$ & $1,56 \mathrm{~b}$ & $1,21 \mathrm{a}$ \\
$\mathrm{v}_{3}$ & $1,10 \mathrm{a}$ & $1,28 \mathrm{a}$ & $1,37 \mathrm{a}$ \\
\hline \hline
\end{tabular}

Keterangan : Angka rata-rata yang diikuti huruf yang sama pada satu faktor perlakuan tidak berbeda nyata menurut Uji Jarak Berganda Duncan pada taraf $5 \%$.

Tabel 2. Pengaruh Trichoderma dan Varietas Bawang Merah terhadap Rata-rata Tinggi Tanaman Umur 4, 5 dan 6 MST (cm).

\begin{tabular}{llll}
\hline \hline & Perlakuan & \multicolumn{3}{c}{ Rata-rata Tinggi Tanaman $(\mathrm{cm})$} \\
\cline { 2 - 4 } & \multicolumn{3}{c}{ 4 MST } \\
\hline \multicolumn{4}{l}{ Trichoderma $(\mathrm{T})$} \\
$\mathrm{t}_{1}$ & $25,27 \mathrm{a}$ & $32,33 \mathrm{a}$ & $37,02 \mathrm{a}$ \\
$\mathrm{t}_{2}$ & $25,72 \mathrm{a}$ & $31,51 \mathrm{a}$ & $36,46 \mathrm{a}$ \\
$\mathrm{t}_{3}$ & $27,18 \mathrm{~b}$ & $32,67 \mathrm{~b}$ & $36,84 \mathrm{a}$ \\
$\mathrm{t}_{4}$ & $25,94 \mathrm{a}$ & $32,10 \mathrm{a}$ & $36,29 \mathrm{a}$ \\
\hline \multicolumn{4}{l}{ Varietas bawang Merah $(\mathrm{V})$} \\
$\mathrm{v}_{1}$ & $24,37 \mathrm{a}$ & $30,62 \mathrm{a}$ & $36,56 \mathrm{a}$ \\
$\mathrm{v}_{2}$ & $27,34 \mathrm{c}$ & $33,12 \mathrm{c}$ & $37,62 \mathrm{~b}$ \\
$\mathrm{v}_{3}$ & $26,38 \mathrm{~b}$ & $32,73 \mathrm{~b}$ & $35,78 \mathrm{a}$ \\
\hline \hline
\end{tabular}

Keterangan : Angka rata-rata yang diikuti huruf yang sama tidak berbeda nyata menurut Uji Jarak Berganda Duncan pada taraf $5 \%$.

Dari tabel diatas terlihat, jenis varietas yang menghasilkan tanaman paling tinggi adalah varietas Ilokos $\left(\mathrm{v}_{2}\right)$, varietas ini secara sigifikan menunjukan hasil tertinggi pada semua hasil pengamatan 4, 5 dan 6 MST, Hal ini sesuai dengan deskripsi Dirjen Hortikultura (2011) bahwa bawang merah varietas Ilokos mempunyai tinggi diatas rata-rata bila dibandingkan varietas Bima dan varietas Sumenep, Adapun efek mandiri perlakuan Trichoderma yang menunjukan hasil terbaik tinggi tanaman adalah jenis T. koningii $\left(\mathrm{T}_{3}\right)$.

Jumlah Daun (helai). Berdasarkan hasil analisis statistik tidak terdapat interaksi perlakuan Trichoderma dan varietas bawang merah terhadap jumlah daun pada pengamatan 4 dan 5 MST, sedangkan pada pengamatan 5 MST pemberian Trichoderma dan varietas 
bawang merah menunjukan adanya perbedaan yang nyata antara perlakuan Trichoderma dan varietas bawang merah. Secara rinci dapat dilihat pada Tabel 3.

Tabel 3. Pengaruh Trichoderma dan Varietas Bawang Merah terhadap Rata-rata Jumlah Daun Tanaman Umur 4, 5 MST (helai).

\begin{tabular}{|c|c|c|}
\hline \multirow[t]{2}{*}{ Perlakuan } & \multicolumn{2}{|c|}{ Rata-rata Jumlah Daun (helai) } \\
\hline & $4 \mathrm{MST}$ & 5 MST \\
\hline \multicolumn{3}{|c|}{ Trichoderma $(\mathrm{T})$} \\
\hline$t_{1}$ & $20,92 \mathrm{a}$ & $33,68 \mathrm{a}$ \\
\hline$t_{2}$ & $21,51 \mathrm{a}$ & $35,36 \mathrm{~b}$ \\
\hline$t_{3}$ & $22,21 \mathrm{a}$ & $35,69 \mathrm{c}$ \\
\hline $\mathrm{t}_{4}$ & $23,19 a$ & $35,00 \mathrm{a}$ \\
\hline \multicolumn{3}{|c|}{ Varietas bawang Merah (V) } \\
\hline $\mathrm{v}_{1}$ & $24,97 a$ & $36,03 b$ \\
\hline $\mathrm{v}_{2}$ & $19,44 a$ & $33,85 a$ \\
\hline $\mathrm{v}_{3}$ & $21,47 \mathrm{~b}$ & $34,91 \mathrm{a}$ \\
\hline
\end{tabular}

Keterangan : Angka rata-rata yang diikuti huruf yang sama tidak berbeda nyata menurut Uji Jarak Berganda Duncan pada taraf $5 \%$,

Pengaruh mandiri Trichoderma yang terbaik terhadap jumlah daun per tanaman pengamatan 5 MST ditunjukan pada perlakuan $t_{3}$ ( $T$. koningii $5 \mathrm{ml} /$ liter) dengan hasil 35,69 helai. Adapun jenis varietas yang menunjukan hasil terbaik terhadap jumlah daun yaitu (varietas Sumenep) yang ditunjukan pada hasil pengamatan 4 MST sebanyak 21,47 helai dan v1 (varietas Bima) yang ditunjukan pada hasil pengamatan 5 MST sebanyak 36,03 helai.

Hasil pengamatan rata-rata jumlah daun 6 MST, perlakuan Trichoderma dan varietas bawang merah menunjukan adanya interaksi. Tabel 4 menunjukkan bahwa terjadi interaksi antara Trichoderma dan varietas bawang merah. Interaksi keduanya ditunjukan pada perlakuan $\mathrm{v}_{2}$ (varietas Ilokos) dengan $\mathrm{t}_{4}$ (Aplikasi $T$. harzianum 2,5 $\mathrm{ml} /$ liter dan $T$. koningii 2,5 $\mathrm{ml}$ /liter) yang menghasilkan rata-rata 35,13 helai daun. Selanjutnya interaksi terbaik ditunjukan dari hasil perlakuan v2 (Varietas Ilokos) dan $t_{3}$ ( $T$. koningii $5 \mathrm{ml} /$ liter), yang menghasilkan rata-rata jumlah daun sebanyak 36,30 helai pada umur 6 MST.

Biomassa per Rumpun (g). Hasil analisis statistik dari Tabel 5 menunjukan bahwa tidak terjadi interaksi antara perlakuan Trichoderma dan varietas bawang merah terhadap rata-rata biomassa bawang merah. Pada pengamatan 4 MST, perlakuan Trichoderma dan varietas bawang merah tidak menunjukan pengaruh sama terhadap biomassa tanaman, Hasil pengamatan umur 5 dan 6 MST terlihat adanya perbedaan yang nyata antar perlakuan Trichoderma. Perlakuan $\mathrm{t}_{3}$ (T. koningii $5 \mathrm{ml} /$ liter) menunjukkan rata-rata biomassa bawang merah tertinggu dibandingkan perlakuan lainnya yaitu sebesar $5.70 \mathrm{~g}$ dan $8,58 \mathrm{~g}$.

Tabel 4. Pengaruh Trichoderma dan Varietas Bawang Merah terhadap Rata-rata Jumlah Daun Tanaman Umur 6 MST (Helai).

\begin{tabular}{ccccccc}
\hline \hline Perlakuan & \multicolumn{2}{c}{$\mathrm{v}_{1}$} & \multicolumn{2}{c}{$\mathrm{V}_{2}$} & \multicolumn{2}{c}{$\mathrm{V}_{3}$} \\
\hline \multirow{2}{*}{$\mathrm{t}_{1}$} & 37,01 & $\mathrm{~A}$ & 36,20 & $\mathrm{~A}$ & 35,95 & $\mathrm{~A}$ \\
& $\mathrm{a}$ & & $\mathrm{a}$ & & $\mathrm{b}$ & \\
$\mathrm{t}_{2}$ & 33,47 & $\mathrm{AB}$ & 36,83 & $\mathrm{~A}$ & 36,97 & $\mathrm{~B}$ \\
& $\mathrm{a}$ & & $\mathrm{b}$ & & $\mathrm{c}$ & \\
$\mathrm{t}_{3}$ & 37,70 & $\mathrm{C}$ & 36,30 & $\mathrm{~B}$ & 34,73 & $\mathrm{~A}$ \\
& $\mathrm{a}$ & & $\mathrm{C}$ & & $\mathrm{b}$ & \\
& 37,60 & $\mathrm{~B}$ & 35,13 & $\mathrm{~B}$ & 36,67 & $\mathrm{~A}$ \\
$\mathrm{t}_{4}$ & $\mathrm{a}$ & & $\mathrm{b}$ & & $\mathrm{a}$ & \\
\hline
\end{tabular}

Keterangan : Angka rata-rata yang diikuti huruf kapital yang sama pada kolom atau huruf kecil yang sama pada baris tidak berbeda nyata menurut Uji Jarak Berganda Duncan pada taraf $5 \%$.

Tabel 5. Pengaruh Trichoderma dan Varietas Bawang Merah terhadap Rata-rata Biomassa Tanaman Bawang Merah Umur 4, 5 dan 6 MST (g).

\begin{tabular}{|c|c|c|c|}
\hline \multirow{2}{*}{ Perlakuan } & \multicolumn{3}{|c|}{ Biomassa Tanaman $(\mathrm{g})$} \\
\hline & $4 \mathrm{MST}$ & $5 \mathrm{MST}$ & $6 \mathrm{MST}$ \\
\hline \multicolumn{4}{|c|}{ Trichoderma $(\mathrm{T})$} \\
\hline$t_{1}$ & $1,65 \mathrm{a}$ & $4,36 \mathrm{a}$ & $6,63 a$ \\
\hline$t_{2}$ & $2,08 a$ & $4,78 \mathrm{a}$ & $7,04 a$ \\
\hline$t_{3}$ & $2,01 \mathrm{a}$ & $5,70 \mathrm{c}$ & $8,58 \mathrm{c}$ \\
\hline$\underline{\mathrm{t}_{4}}$ & $2,17 \mathrm{a}$ & $5,30 \mathrm{~b}$ & $7,54 \mathrm{~b}$ \\
\hline \multicolumn{4}{|c|}{ Varietas bawang Merah (V) } \\
\hline $\mathrm{v}_{1}$ & $1,96 a$ & $5,05 a$ & 7,14a \\
\hline $\mathrm{v}_{2}$ & $2,15 a$ & $5,36 a$ & $7,67 a$ \\
\hline $\mathrm{V}_{3}$ & $1,82 \mathrm{a}$ & 4,70a & $7,54 a$ \\
\hline
\end{tabular}

Keterangan : Angka rata-rata yang diikuti huruf yang sama tidak berbeda nyata menurut Uji Jarak Berganda Duncan pada taraf $5 \%$.

Jumlah Anakan per Rumpun. Perlakuan Trichoderma dan varietas bawang merah tidak menunjukan adanya interaksi, namun secara mandiri $\mathrm{v}_{1}$ (Varietas Bima) menunjukan hasil terbaik jika dibandingkan dengan 2 vaietas lainya yang digunakan sebagai objek penelitian, $\mathrm{v}_{1}$ (Varietas Bima) menghasilkan anakan terbanyak dengan rata-rata 8,90 siung. Hasil analisis statistik jumlah umbi tanaman bawang merah per rumpun dapat dilihat pada Tabel 6 .

Diameter Umbi Kering per Petak (cm). Hasil analisis statistik diameter umbi per rumpun secara rinci dapat dilihat pada Tabel 7 . 
Hasil analisis statistik menunjukan bahwa antara perlakuan Trichoderma dan varietas bawang merah tidak terdapat interaksi terhadap diameter umbi per petak. Baik perlakuan Trichoderma maupun varietas yang menunjukkan perlakuan terbaik

Tabel 6. Pengaruh Trichoderma dan Varietas Bawang Merah terhadap Rata-rata Anakan Tanaman Bawang Merah (siung).

\begin{tabular}{lc}
\hline \hline Perlakuan & Jumlah Anakan per Rumpun \\
\cline { 2 - 2 } & $($ siung) \\
\hline Trichoderma $(\mathrm{T})$ & $7,27 \mathrm{a}$ \\
$\mathrm{t}_{1}$ & $8,28 \mathrm{a}$ \\
$\mathrm{t}_{2}$ & $7,93 \mathrm{a}$ \\
$\mathrm{t}_{3}$ & $7,37 \mathrm{a}$ \\
$\mathrm{t}_{4}$ & \\
\hline Varietas bawang Merah $(\mathrm{V})$ & $8,90 \mathrm{~b}$ \\
$\mathrm{v}_{1}$ & $6,97 \mathrm{a}$ \\
$\mathrm{v}_{2}$ & $7,28 \mathrm{a}$ \\
$\mathrm{v}_{3}$
\end{tabular}

Keterangan : Angka rata-rata yang diikuti huruf yang sama tidak berbeda nyata menurut Uji Jarak Berganda Duncan pada taraf $5 \%$.

Tabel 7. Pengaruh Trichoderma dan Varietas Bawang Merah terhadap Rata-rata Diameter Umbi Bawang Merah (cm).

\begin{tabular}{lc}
\hline \hline Perlakuan & Diameter Umbi \\
\cline { 2 - 2 } & $(\mathrm{cm})$ \\
\hline Trichoderma $(\mathrm{T})$ & \\
$\mathrm{t}_{1}$ & $2,30 \mathrm{a}$ \\
$\mathrm{t}_{2}$ & $2,43 \mathrm{a}$ \\
$\mathrm{t}_{3}$ & $2,49 \mathrm{a}$ \\
$\mathrm{t}_{4}$ & $2,11 \mathrm{a}$ \\
\hline Varietas bawang Merah $(\mathrm{V})$ & \\
$\mathrm{v}_{1}$ & $2,59 \mathrm{a}$ \\
$\mathrm{v}_{2}$ & $2,53 \mathrm{a}$ \\
$\mathrm{v}_{3}$ & $1,88 \mathrm{a}$ \\
\hline \hline
\end{tabular}

Keterangan : Angka rata-rata yang diikuti huruf yang sama tidak berbeda nyata menurut Uji Jarak Berganda Duncan pada taraf $5 \%$.

Bobot Umbi kering per Rumpun (g). Tidak terdapat interaksi antara perlakuan Trichoderma dan varietas bawang merah terhadap rata-rata bobot umbi segar dan bobot umbi kering per rumpun. Tabel 8, menunjukkan perlakuan Trichoderma secara mandiri ditunjukkan pada perlakuan $\mathrm{t}_{4}(\mathrm{~T}$. harzianum $2,5 \mathrm{ml} /$ liter dan $T$. koningii 2,5 ml/liter) dengan hasil 100,08 gram per rumpun dan $\mathrm{t}_{3}$ (Aplikasi T. koningii $5 \mathrm{ml} /$ liter) dengan hasil 102,95 gram per rumpun. Sedangkan secara mandiri varietas yang menunjukan hasil terbaik yaitu $v_{3}$ (varietas Sumenep) dengan hasil
101,30 gram per rumpun dan $v_{2}$ (varietas Ilokos) dengan hasil 101,41 gram per rumpun.

Tabel 8. Pengaruh Trichoderma dan Varietas Bawang Merah terhadap Rata-rata Bobot Umbi Kering Bawang Merah per Rumpun (g).

\begin{tabular}{lr}
\hline \multirow{2}{*}{ Perlakuan } & \multicolumn{1}{c}{ Bobot Umbi per Rumpun } \\
\cline { 2 - 2 } Trichoderma $(\mathrm{T})$ & \\
$\mathrm{t}_{1}$ & $92,13 \mathrm{a}$ \\
$\mathrm{t}_{2}$ & $97,04 \mathrm{a}$ \\
$\mathrm{t}_{3}$ & $102,95 \mathrm{c}$ \\
$\mathrm{t}_{4}$ & $100,08 \mathrm{~b}$ \\
\hline Varietas bawang Merah $(\mathrm{V})$ & \\
$\mathrm{V}_{1}$ & $91,44 \mathrm{a}$ \\
$\mathrm{v}_{2}$ & $101,41 \mathrm{c}$ \\
$\mathrm{v}_{3}$ & $101,30 \mathrm{~b}$ \\
\hline \hline
\end{tabular}

Keterangan : Angka rata-rata yang diikuti huruf yang sama tidak berbeda nyata menurut Uji Jarak Berganda Duncan pada taraf $5 \%$.

Bobot Umbi Kering per Petak (kg). Hasil Trichoderma dan Varietas Bawang Merah menunjukan adanya interaksi terhadap rata-rata bobot umbi kering per petak.

Tabel 9. Pengaruh Trichoderma dan Varietas Bawang Merah terhadap Rata-rata Bobot Umbi Kering Bawang Merah per Petak (Kg).

\begin{tabular}{cccccccc}
\hline \hline Perlakuan & \multicolumn{2}{c}{$\mathrm{v}_{1}$} & & \multicolumn{2}{c}{$\mathrm{v}_{2}$} & \multicolumn{2}{c}{$\mathrm{v}_{3}$} \\
\hline \multirow{2}{*}{$\mathrm{t}_{1}$} & 4,75 & $\mathrm{~A}$ & 4,97 & $\mathrm{~A}$ & 4,93 & $\mathrm{~A}$ \\
& $\mathrm{~A}$ & & $\mathrm{a}$ & & $\mathrm{a}$ & \\
$\mathrm{t}_{2}$ & 4,63 & $\mathrm{~A}$ & 5,03 & $\mathrm{~A}$ & 5,27 & $\mathrm{~A}$ \\
& $\mathrm{~A}$ & & $\mathrm{a}$ & & $\mathrm{b}$ & \\
$\mathrm{t}_{3}$ & 5,35 & $\mathrm{~B}$ & 5,42 & $\mathrm{~B}$ & 4,87 & $\mathrm{~A}$ \\
& $\mathrm{~B}$ & & $\mathrm{~b}$ & & $\mathrm{~b}$ & \\
& 4,87 & $\mathrm{~A}$ & 4,72 & $\mathrm{~A}$ & 5,32 & $\mathrm{~A}$ \\
$\mathrm{t}_{4}$ & $\mathrm{~A}$ & & $\mathrm{a}$ & & $\mathrm{b}$ & \\
\hline \hline
\end{tabular}

Keterangan : Angka rata-rata yang diikuti huruf yang sama pada kolom atau baris tidak berbeda nyata menurut Uji Jarak Berganda Duncan pada taraf $5 \%$.

Pada Tabel 9 terlihat bahwa terjadi interaksi antara Trichoderma dan varietas bawang merah. Interaksi keduanya ditunjukan pada perlakuan $\mathrm{v}_{1}$ (Varietas Bima) dengan $\mathrm{f}_{3}$ (T. koningii $5 \mathrm{ml} /$ liter) yang menghasilkan bobot umbi kering rata-rata $5,35 \mathrm{~kg}$ per petak. Interaksi terbaik ditunjukan dari hasil perlakuan $\mathrm{v}_{2}$ (Varietas Ilokos) dan $t_{3}(T$. koningii $5 \mathrm{ml} /$ liter), menghasilkan bobot umbi kering rata-rata $5,42 \mathrm{~kg}$ per petak.

Analisis Korelasi Antara Komponen Pertumbuhan dan Hasil Umbi Kering per Petak. Berdasarkan pengamatan dan perhitu- 
ngan komponen pertumbuhan dan hasil tanaman penelitian, maka didapatkan perhitungan korelasi sebagai berikut (lihat Tabel 10).

\begin{tabular}{|c|c|c|c|}
\hline \multirow{2}{*}{ Uraian } & \multicolumn{3}{|c|}{ Tinggi Tanaman } \\
\hline & $4 \mathrm{MST}$ & $5 \mathrm{MST}$ & $6 \mathrm{MST}$ \\
\hline Nilai $\mathrm{r}$ & 0,360 & 0,153 & 0,268 \\
\hline Kategori $\mathrm{r}$ & Rendah & $\begin{array}{l}\text { Sangat } \\
\text { Rendah }\end{array}$ & Rendah \\
\hline Nilai $r^{2}$ & 0,129 & 0,023 & 0,072 \\
\hline Nilai t & 2,247 & 0,901 & 1,620 \\
\hline Nilai $t_{0,025(25)}$ & 2,060 & 2,060 & 2,060 \\
\hline Kesimpulan & Nyata & $\begin{array}{l}\text { Tidak } \\
\text { Nyata }\end{array}$ & Tidak Nyata \\
\hline \multirow[t]{2}{*}{ Uraian } & \multicolumn{3}{|c|}{ Jumlah Daun } \\
\hline & 4 MST & $5 \mathrm{MST}$ & $6 \mathrm{MST}$ \\
\hline Nilai $\mathrm{r}$ & $-0,135$ & 0,368 & 0,358 \\
\hline Kategori $\mathrm{r}$ & $\begin{array}{c}\text { Tidak } \\
\text { Berkorelasi }\end{array}$ & Rendah & Rendah \\
\hline Nilai $\mathrm{r}^{2}$ & 0,018 & 0,135 & 0,128 \\
\hline Nilai $t$ & $-0,793$ & 2,307 & 2,237 \\
\hline Nilai $t_{0,025(25)}$ & 2,060 & 2,060 & 2,060 \\
\hline Kerelasi & $\begin{array}{l}\text { Tidak } \\
\text { Nyata }\end{array}$ & Nyata & Nyata \\
\hline \multirow[t]{2}{*}{ Uraian } & \multicolumn{3}{|c|}{ Biomassa } \\
\hline & 4 MST & $5 \mathrm{MST}$ & $6 \mathrm{MST}$ \\
\hline Nilai $\mathrm{r}$ & $-0,004$ & $-0,055$ & 0,147 \\
\hline Kategori $\mathrm{r}$ & $\begin{array}{c}\text { Tidak } \\
\text { Berkorelasi }\end{array}$ & $\begin{array}{c}\text { Tidak } \\
\text { Berkorelas }\end{array}$ & Rendah \\
\hline Nilai $r^{2}$ & 0,000 & 0,003 & 0,022 \\
\hline Nilai $t$ & $-0,022$ & $-0,324$ & 0,865 \\
\hline Nilai $t_{0,025(25)}$ & 2,060 & 2,060 & 2,060 \\
\hline Kerelasi & $\begin{array}{l}\text { Tidak } \\
\text { Nyata }\end{array}$ & $\begin{array}{l}\text { Tidak } \\
\text { Nyata }\end{array}$ & Tidak Nyata \\
\hline
\end{tabular}

Berdasarkan analisis hasil perhitungan uji korelasi, terdapat korelasi antara komponen pertumbuhan dan hasil tanaman bawang merah (Allium ascalonicum.) dapat dilihat pada Tabel 10 diatas menunjukan bahwa nilai korelasi antara tinggi tanaman 4 MST dengan bobot umbi kering per petak menunjukan adanya hubungan yang nyata, karena setelah dilakukan uji $\mathrm{t}$ diperolah bahwa $t_{\text {hitung }}>t_{\text {tabel, }}$ sedangkan antara tinggi tanaman dengan bobot umbi kering per petak pada umur tanaman 5 dan 6 MST, dari hasil analisis menunjukan adanya korelasi yang tidak nyata, karena setelah dilakukan uji $\mathrm{t}$ diperoleh bahwa $t_{\text {hitung }}>t_{\text {tabel. }}$. Berdasarkan hasil analisis koefisien didapatkan determinasi $\left(\mathrm{r}^{2}\right)$ diperoleh secara berturut-turut : 2.247, 2.060 dan 1.620, artinya bahwa hasil bawang merah per petak dipengaruhi oleh tinggi tanaman 4 MST sebesar $22,47 \%$ dengan kategori rendah, pada umur 5
MST hasil bawang merah per petak tidak dipengaruhi sebesar 20,60 \% dengan kategori sangat rendah, dan hasil bawang merah per petak tidak dipengaruhi oleh tinggi tanaman 6 MST sebesar $16.20 \%$ dengan kategori rendah.

Korelasi antara jumlah daun dengan bobot umbi kering per petak tidak menunjukan hubungan korelasi yang nyata pada hasil pengamatan jumlah daun 4 MST, karena setelah dilakukan uji $\mathrm{t}$ diperoleh bahwa thitung $<\mathrm{t}_{\text {tabel. }}$ Sedangkan pada pengamatan jumlah daun umur 5 dan 6 MST, menunjukan adanya korelasi yang nyata karena setelah dilakukan uji $\mathrm{t}$ diperoleh bahwa $t_{\text {hitung }}>t_{\text {tabel. }}$. Berdasarkan hasil analisis koefisien determinasi $\left(\mathrm{r}^{2}\right)$ diperoleh secara berturut-turut : 0.018, 0,135 dan 0,128, artinya bahwa hasil bawang merah per petak tidak dipengaruhi oleh tinggi tanaman 4 MST sebesar $1,8 \%$ dengan kategori tidak berkorelasi, pada umur 5 MST hasil bawang merah per petak dipengaruhi sebesar 13,5 \% dengan kategori rendah, dan hasil bawang merah per petak tidak dipengaruhi oleh tinggi tanaman 6 MST sebesar $12,8 \%$ dengan kategori rendah.

Dari hasil analisis korelasi biomassa dengan bobot umbi kering per petak tidak menunjukan adanya hubungan korelasi pada semua umur pengamatan karena setelah dilakukan uji $t$ diperoleh bahwa $t_{\text {hitung }}<t_{\text {tabel. }}$. Berdasarkan hasil analisis koefisien determinasi $\left(\mathrm{r}^{2}\right)$ diperoleh secara berturut-turut : 0,000, 0,003 dan 0,022, artinya bahwa hasil bawang merah per petak tidak dipengaruhi oleh tinggi tanaman 4 MST sebesar $0 \%$ dengan kategori tidak berkorelasi, pada umur 5 MST hasil bawang merah per petak dipengaruhi sebesar $0,3 \%$ dengan kategori tidak berkorelasi, dan hasil bawang merah per petak tidak dipengaruhi oleh tinggi tanaman 6 MST sebesar 2,2 \% dengan kategori rendah.

Dengan demikian dapat disimpulkan bahwa tinggi tanaman umur 4 MST serta jumlah daun umur 5 dan 6 MST merupakan indikasi adanya perningkatan terhadap hasil bobot umbi kering per petak. Maka, semakin tinggi tanaman dan banyak daun akan semakin meningkatnya hasil produksi tanaman bawang merah.

Sejalan dengan pendapat Subhan (1991), bahwa potensi hasil bawang putih tergantung pada laju pertumbuhan vegetatif sebelum membentuk umbi. Estu Rahayu dan Nur Berlian (2004), yang mengatakan bahwa tanaman bawang merah yang pertumbuhanya baik yang dicirikan dengan daun yang lebih tinggi dan banyak dapat menghasilkan umbi yang lebih 
besar dan produksi yang lebih tinggi, ditambahkan Subhan (2002), bahwa makanan yang dihasilkan pada saat pertumbuhan vegetatif disimpan dalam umbi, sehingga tingginya hasil panen dipengaruhi oleh karbohidrat yang dapat disimpan dalam umbi. Menurut Hendro Soenarjono (1990), bila tanaman tumbuhnya lebih sehat kekar, kompak dan dipupuk dengan takaran yang cukup, maka akan diperoleh umbi yang besar, sehingga bobotnya lebih tinggi.

\section{Kesimpulan}

Terdapat pengaruh interaksi yang nyata antara Trichoderma dan varietas bawang merah terhadap parameter rata-rata jumlah daun 6 MST. Trichoderma secara mandiri berpengaruh nyata pengendalian penyakit moler. Terdapat efek mandiri dari perlakuan Trichoderma terhadap rata-rata tinggi tanaman 4 dan 5 MST, jumlah daun 5 MST, biomassa tanaman 5 dan 6 MST, dan bobot umbi kering per rumpun, serta efek mandiri varietas bawang merah pada ratarata tinggi tanaman 4, 5 dan 6 MST, jumlah daun 4 dan 5 MST, jumlah anakan per rumpun dan bobot umbi kering per rumpun.

Terdapat korelasi yang nyata antara komponen pertumbuhan tinggi tanaman umur 4 MST dan jumlah daun umur 5 dan 6 MST dengan hasil bobot umbi kering per petak.

Berdasarkan kesimpulan diatas, maka peneliti menyarankan sebagai berikut :

1. Varietas Bima dengan $\mathrm{t}_{3}$ (T. koningii $5 \mathrm{ml} /$ liter) serta $v_{2}$ Varietas Ilokos dengan $t_{3}$ (T. koningii 5 $\mathrm{ml} /$ liter), dapat direkomendasikan kepada para petani di Cirebon dalam upaya mencegah serangan penyakit moler dan upaya meningkatkan hasil tanaman bawang merah.

2. Variatas Ilokos dapat direkomendasikan sebagai varietas alternatif untuk ditanam di Cirebon selain menggunakan varietas lokal (varietas Bima).

3. Untuk mendapatkan rekomendasi yang lebih tepat perlu dilakukan penelitian lebih lanjut terutama untuk beberapa daerah dan jenis tanah yang berbeda.

\section{Daftar Pustaka}

Badan Pusat Statistik, 2013. Publikasi Staitistik Pertanian. http://st2013.bps.go.id/dev2/
index.php/site/topik?kid=3\&kategori=Tan aman-Hortikultura. Diakses 10 April 2016.

Samadi, B; B Cahyono (2005). Bawang Merah Intensifikasi usaha tani. Yogyakarta: Kanisius. ISBN 979-497-323-8

Departemen Pertanian. 2003. Metode Pengamatan OPT Tanaman Sayuran. (On-line). http:// www.deptan.go.id diakses 1 Maret 2006.

Departemen Pertanian. 2007. Prospek Dan Arah Pengembangan Agribisnis Bawang Merah. Jakarta.

Dinas Pertanian tanaman Pangan, Proviinsi Jawa Barat. 2013. Potensi Pengembangan Tanaman Sayur-sayuran Unggulan di Jawa Barat. http://diperta.jabarprov.go.id/index.php/ subMenu/924 diakses tanggal 12 April 2016.

Gerbang Pertanian, 2011. Trichoderma Sp Sebagai Pupuk Biologis dan Biofungisida. http:// www.gerbangpertanian.com/2011/02/tric hoderma-sp-sebagai-pupuk-biologis.html. Diakses tanggal 12 Maret 2016.

Hapsah dan Y. Hasanah. 2011. Budidaya Tanaman Obat dan Rempah. Medan : USU Press

Nurwardani P. 1996. Pengendalian Hayati Penyakit Layu Fusarium oxysporum Pada tanaman Melon dengan Perbanyakan Masal Agen Pengendali Hayati. Tesis Program Pasca Sarjana Universitas Brawijaya Malang. 112 Hal.

Nuryani W dan Djatnika, 1999. Pengendalian Bercak Bunga Sedap Malam dengan BIO-GL dan BIO-TRI. Prosiding Kongres Nasional XV dan Seminar Ilmiah PFI Purwokerto, 16-18 September

Pitojo, Setijo. 2003. Budidaya Bawang Merah. Penebar Swadaya. Jakarta. $55 \mathrm{hlm}$.

Prabowo, A.K.E., N. Prihatiningsih, dan L. Soesanto. 2006. Potensi Trichoderma harzianum dalam mengendalikan sembilan isolat Fusarium oxysporum Schlecht. f.sp. zingiberi Trujillo pada kencur. Jurnal Ilmu-Ilmu Pertanian Indonesia 8(2):76-84.

Rahayu, E. dan N.V.A. Berlian. 2005. Bawang Merah. Penebar Swadaya. Jakarta. 94 hal

Rokhlani. 2005. Potensi Pseudomonas fluorescens P60, Trichoderma harzianum, dan Gliocladium sp. Dalam Menekan Fusarium oxysporum f.sp. gladioli In Vitro dan In Planta. Skripsi. Fakultas Pertanian Universitas Jenderal Soedirman, Purwokerto. 58 hal. (Tidak Dipublikasikan).

Rosmahani, I., E. Korlina, Baswarsiati, E. Retnaningtyas, A. Suryadi, S.Z. Sa'adah, 
dan Sukur. 2003. Sistem Usaha Tani Berbasis Bawang Merah di Lahan Kering Dataran Rendah (On-line). http://www.bbpt-jatim. deptan.go.id diakses 1 Maret 2006

Samuael, G.J., Caverri, P., Farr, D.F., and E.B, McCray. 2010. Trichoderma Oline, Systemic Mycologi And Microbilology Laboratory, ARS, USDA

Sudantha, I.D. 2003. Pengaruh Kadar Air Tanah Tersedia Terhadap Aktivitas Jamur Trichoderma Harzianum Dalam Menekan Jamur Sclerotium Rolfsii Pada Tanaman Kedelai. Jurnal Penelitian 2(4):24-30.
Warsa, T dan C. S. Akhyar., 1982. Teknik Perancangan Percobaan (Rancangan dan Analisis). Fakultas Pertanian Unpad, Bandung

Wibowo, S. 2007. Budidaya Bawang Putih, Merah dan Bombay. Jakarta : Penebar Swadata, cet 16

Wijaya, 2000. Analisis Statistik dengan Program SPSS 10,0. Alfabeta, Bandung

Wiyatiningsih, S. 2007. Kajian Epidemi Penyakit Moler pada Bawang Merah. (On-line). http://pasca.ugm.ac.id/id/promotion view.p hp?dc id=6. Diakses tanggal 13 Maret 2009. 